\title{
The Problem of Individuality in Hermann Cohen's Aesthetics
}

\author{
Ezio Gamba \\ Theological University of Northern Italy - Turin Campus \\ Via XX Settembre, 83, I-10122, Turin, Italy
}

\begin{abstract}
Franz Rosenzweig devoted particular attention to the problem of individuality in Hermann Cohen's philosophy. He writes that, in comparison with the individuality of the man of religion, "the human being about which aesthetics knew [...] fades now in all its aesthetic individuality to a "mere type"'. This statement is actually based on Cohen's writings: in Ästhetik des reinen Gefühls (1912), Cohen explicitly maintains that the human being that is the object of artistic representation is not a type, but rather an individual. Just three years later, however, in his first book about philosophy of religion, Der Begriff der Religion im System der Philosophie (1915), Cohen states that the human being that is represented by art is not really an individual; only the man of religion is really individual; the human being represented by art is merely a type.

In this paper my aim is to argue for the thesis that these opposite statements belong to different points of view. From an aesthetic point of view the human being represented by art has to be considered as truly individual, but the systematic overview adopted in Der Begriff der Religion can teach us that the individuality of the human being represented by art can't be maintained from a different point of view than the aesthetic one.
\end{abstract}

Key words: Hermann Cohen, Franz Rosenzweig, aesthetics, individuality, art

\section{Article history:}

The article was submitted on 05.06.2019

The article was accepted on 10.07.2019

For citation: Ezio Gamba. The Problem of Individuality in Hermann Cohen's Aesthetics. RUDN Journal of Philosophy. 2019; 23 (4):413 - 419. doi: 10.22363/2313-2302-2019-23-4-413-419

As is well known, Franz Rosenzweig devoted particular attention to the problem of individuality in Hermann Cohen's philosophy and to the overcoming of every concept of individuality we can find in System der Philosophie by the more authentic individuality of the man of religion (Mensch der Religion): regarding this topic Rosenzweig stated that the need to deepen the problem of individuality led Cohen (after writing the third part of his System der Philosophie) to write two books about religion, instead of his planned work about philosophical psychology [1. P. XLII-XLIV and XLVI-

(C) Gamba E., 2019.

(c) (1) This work is licensed under a Creative Commons Attribution 4.0 International License https://creativecommons.org/licenses/by/4.0/ 
XLVII; also as 2. P. 204-205 and 206-207]. Rosenzweig writes that, in comparison with the individuality of the man of religion (an individuality founded on the correlation with God), "the human being about which aesthetics knew [...] fades now in all its aesthetic individuality to a "mere type"",

Rosenzweig's statement is actually based on Cohen's writings about aesthetics and about religion: in the last part of his System der Philosophie, Ästhetik des reinen Gefühls (1912), Cohen explicitly maintains that the human being that is the object of artistic representation or the character of a work of literature is not a type, but rather an individual. Just three years later, however, in his first book about philosophy of religion, Der Begriff der Religion im System der Philosophie (1915), Cohen states that the human being that is represented by art is not really an individual: only the man of religion is really individual; the human being represented by art (or the character of a work of literature) is merely a type ${ }^{2}$.

This statement by Cohen is not accompanied by an acknowledgement that an explicit recantation of his previous view is necessary. Cohen doesn't claim to correct his positions of three years earlier; on the contrary, he states that "the aesthetic analysis of the true object in the work of art is sufficient to teach us that this object can't be an individual, but rather merely a type"3. Does Cohen refer to his own aesthetic analyses, which he presented in his own aesthetic writings and above all in Ästhetik des reinen Gefühls? The hypothesis that Cohen refers to some different analyses from the ones that are exposed in his writings would look extremely unlikely, but in Ästhetik des reinen Gefühls the individuality of the human being represented by art is explicitly maintained. On the other hand, if we suppose that Cohen, since the publication of Ästhetik des reinen Gefühls, developed his own aesthetic thought and that, on this not secondary point, he went beyond his theses presented in Ästhetik des reinen Gefühls, we have to acknowledge that there is no trace of this development in Cohen's published writings. And, above all, we have to acknowledge that we don't find any word about this development in Hermann Cohen's summary of Ästhetik des reinen Gefühls that makes up the first part of his essay about Mozart published in 1916, one year after Der Begriff der Religion ${ }^{4}$.

Should we think that Cohen's statements in Der Begriff der Religion are the result of a mere mistake or inconsistency by Cohen? In this paper my aim is to argue for the thesis that the statement we read in Der Begriff der Religion, according to which

${ }^{1}$ [1. P. XLVI; also as 2. P. 207]. (“[...] verblaßt nun [...] der Mensch, von dem die Ästhetik wußte [...] in all seiner ästhetischen Individualität zu einem 'bloßen Typus'”).

${ }_{2}$ [3. P. 86-87, 91-92 and 98]. In Ästhetik des reinen Gefühls, it is important to notice, Cohen entitles individuality not only to the human being that is the object of artistic representation, but also to aesthetic consciousness; however, Rosenzweig's statement that in comparison to the man of religion the individual of aesthetics results a mere type can't but refer to these pages of Der Begriff der Religion im System der Philosophie, that clearly concern the human being as the object of artistic representation, not aesthetic consciousness.

${ }^{3}$ [3. P. 86]. "[...] so lehrt uns schon die ästhetische Analyse des eigentlichen Gegenstands im Kunstwerk, daß dies nicht ein Individuum sein kann, sondern nur ein Typus".

${ }^{4}$ [4; also as 5]. Hartwig Wiedebach demonstrated [see the note in 5. P. 2] that, even if on the frontispiece of the first edition is written "1915", the actual year of publication of Die dramatische Idee in Mozarts Operntexten is 1916. 
the human being represented by art is a type, and the statement we read in Ästhetik des reinen Gefühls, according to which the human being represented by art is truly individual, belong to different levels or points of view, and therefore they don't contradict one another. According to this thesis, the aesthetic analysis would show us that from an aesthetic point of view the human being represented by art has to be considered as truly individual, but the systematic overview that is adopted in Der Begriff der Religion can teach us that the individuality of the human being represented by art can't be maintained from a different point of view than the aesthetic one.

To understand this thesis, let's examine Cohen's considerations about the individuality of the object of artistic representation in Ästhetik des reinen Gefühls. Here Cohen asks whether the human being we see in a painting (or the character of a literary work) is a representation of the concept of human being, whether it is an authentic individual, or whether it is rather a type, that is an universal represented by a single figure that expresses a character (as the lover, the hero, the miser) in an eminent way. The first of these three hypotheses is immediately rejected, because it surely doesn't fit the experience we have of works of art.

In addition, the hypothesis according to which the human being represented in a painting or described in a work of literature is a type is unsatisfactory when we confront it with real works of art and with the experience we have of these works: certainly in these works we find representations and characters that are just types; but could characters such as Hamlet or Faust be considered to be types? In comparison with the strong individuality of these characters, types seem to be relegated to the role of secondary characters, and an art that represents figures as just types seems to be failed art.

Thus it appears necessary that the human being represented by art is authentically individual; however, this need seems to be contradicted by a serious problem. It could seem that every artistic representation of an object is founded on the knowledge of the represented object itself. Cohen's critical idealism, however, denies the possibility of knowledge of individual (or presumed to be individual) objects, because all knowledge has products of thought as its objects, and products of thought, as concepts, are always, in principle, universal. So the individual has no different meaning or role than the role of a limit-concept of knowledge; knowledge tends, in its polarity of directions, toward two different ideal limits: the law of all phenomena, and the complete determination of the individual; every supposedly individual object is actually a universal, as a product of thought [6. Vol. I. P. 365]. The knowledge we have of a human being is always conceptual, so it is knowledge of a universal [6. Vol. I. P. 357]. It could seem, at first sight, that sensation could overcome this problem; the perceived individual, indeed, doesn't seem having a merely conceptual existence. However, it is necessary to remember that objects of sensation, in Cohen's idealism, are not independent from thought; on the contrary, they are products that have their origin in thought itself. So sensation too, as a factor of knowledge, has no individual objects ${ }^{5}$; if we think we can overcome the im-

5 About the meaning of sensation for the question of individuality, see [7. P. 168, 434-436, 470 - 473 and 488]. 
possibility of thinking an individual object by pointing a finger at it, we put ourselves outside of the field of knowledge [6. Vol. I. P. 357].

But if the individual can't be an object of knowledge, how can art represent it? Can art succeed in representing an individual object that can't be an object of knowledge? We have now to recall the fact that the production of the human figure that is the object of artistic representation is not founded on knowledge, but on pure feeling. It is pure feeling, in its psychological interpretation as love for the human being ${ }^{6}$, to produce this figure.

At the same time, however, artistic representation can't do without conceptual knowledge, which is an essential precondition of art. Cohen hereto reminds us that all the contents of consciousness in general, when we don't restrict ourselves to reflections about knowledge alone, are not mere conceptual constructions, because annexes of relative feeling are always essential to them. Cohen points out that we can't think that our acquaintance with people around us or with familiar landscapes is mere conceptual knowledge (and so, necessarily, knowledge of universals) [6. Vol. I. P. 365]; our acquaintance with these objects can't be reduced to conceptual knowledge, but it has a fundamental affective component. This affective component is what according to Cohen makes this acquaintance able to have really individual objects; the object of conceptual thought is necessarily universal, but the object of feeling is necessarily individual. Certainly this consideration about common experience can't be considered as a proof to found the individuality of the objects of art (because the common experience of acquaintance between people is not a fact of culture that could act as material for a real transcendental reflection); rather, this consideration is just a reminder that convincingly points out how abstract, unilateral and unsufficient is to consider the contents of consciousness on the mere base of their conceptual content.

Thus, the possibility of the artistic representation or literary description of individuals is also the possibility that pure feeling, that is the foundation of artistic creation, and conceptual thought, as a precondition of artistic creation, reach a unitary expression. In this unitary expression, however, pure feeling has to play the role of the only foundation. The last chapter of the first volume of Ästhetik des reinen Gefühls is indeed devoted (in its paragraphs about language and poetry) to explaining the possibility of this unitary expression that is founded on pure feeling.

Now we can actually consider how in Der Begriff der Religion, just three years later, Cohen denies authentic individuality to the human being that is represented in works of art. First of all we have to underscore that in Der Begriff der Religion Cohen never presents reflections that have the individual represented by art as their main topic. The individual represented by art is always considered by Cohen, in Der Begriff der Religion, in comparison with the individual that, in correlation with God, makes up the content of religion. The aim of this comparison is to distinguish between religious love and aesthetic love - a distinction that is the main aim of the chapter of Der Begriff der Religion devoted to the relation between religion and aesthetics. As such, the individuality of the human being that is represented by art is denied only in comparison with

${ }^{6}$ On love as psychological interpretation of pure feeling, see [3. P. 88]. 
the more authentic individuality of the man of religion, of the individual in correlation with God. So from the point of view of this comparison Rosenzweig's statement that was quoted at the beginning of this paper really seems to hit the mark. Rather than a simple denial of the individuality of the human being that is represented by art, we have an overcoming of the individuality of this object by the more authentic individuality of the man of religion. This individuality, according to Cohen, is more authentic as a consequence of the fact that religious love, unlike aesthetic love, considers the human being in its correlation with God; from the point of view of religion, the single human being, in its correlation with God, should never be considered as subordinated to any universal concept, not even to the couple composed by the nature of man and the man of nature; because of that Cohen writes that the man of religion is absolutely (schlechtin) individual [3. P. 91-92, 98]. Only in comparison with this more authentic or absolute individuality does Cohen use the word "type" to define the human being that is represented by art.

Certainly this interpretation has a serious problem: can we say that an individual is less individual than another? Individuality doesn't seem to be a quantifiable property, so it is unlikely that we can compare two objects to determine which of them is the more individual. However, it is necessary to clarify that the comparison between the human being represented by art and the man of religion is not a comparison between two objects, but rather between two different determinations of individuality; Cohen's thesis, therefore, is that the religious determination of individuality is a more authentic determination of individuality than the aesthetical. Even from this point of view, however, we seem to find a mere repetition of the same problem. Can we say that a determination of individuality is better, or more authentic, than another?

To meet this objection, it is useful to recall that the individual that is the object of artistic representation always has a universal value, because pure feeling produces the represented human being as an ideal of the individual, or better as an ideal of individualization; this is fully evident when the human being is represented without consideration of its historical or contingent features (as in the Greek kouros), but it is the same in regard to the representation of an individual that is determined by historical or other contingent features. All these features, indeed, belong to the field of knowledge, so they don't undermine the ideal value (founded in pure feeling) of the human being represented by art. The individual represented by art, therefore, is not a type, i.e. a universal represented by a seemingly individual figure, but rather an individual endowed with universal or ideal value. Perhaps we can therefore state that Cohen, in comparing the human being represented by art with the man of religion, uses the word "type" (in a not fully correct way and contradictorily with Cohen's statements in Ästhetik des reinen Gefühls) to state this double value (individual and universal or ideal) of the human being represented by art.

An analogous universal value should not be considered when it comes to the man of religion, that has to be conceived only singularly in his correlation with God; the individuality of the man of religion is therefore absolute individuality (absolute Individualität) [3. P. 92]. From this point of view the human being produced by artistic representation, for its universal value, appears, in comparison with the absolute individu- 
ality of the man of religion, to be similar to the type, even if it is not a type; types, indeed, are not really individual. Actually, in the quotation from Der Begriff der Religion I cited above, Cohen denies that the human being represented by art is an individual. Regarding this clear denial, Der Begriff der Religion and Ästhetik des reinen Gefühls seem to be in explicit contradiction; it is on this specific topic, however, that my aim is to explain that the opposite statements we read in those works by Cohen belong to different points of view, so they don't really contradict each other.

How can Cohen deny that the individual that is the object of artistic representation is authentically individual? He can deny that because the human being represented by art is not even a true human being; art is always illusion, fiction. This concept of art as illusion is already expressed in Ästhetik des reinen Gefühls, but it seems to become crucial for the problem of the individuality of the object of artistic representation in Der Begriff der Religion ${ }^{7}$. The human being represented by art is not a true human being, but rather an illusion; so its individuality is the individuality of an illusion, contrary to the man of religion. The human being represented by art is therefore only individual for aesthetic consciousness (in artistic creation and in aesthetic Erlebnis, the aesthetic experience that is among the essential topics of philosophical aesthetics). Adopting a different point of view, a point of view external to aesthetics (as the systematic overview adopted in Der Begriff der Religion, where Cohen's aim is to examine the specificity [Eigenart] of religion in relation to the system of philosophy as a whole and to each of its directions), it is however necessary to acknowledge that the individual human being represented by art is just illusion, whereas its universal or ideal value is authentic. So, even if Cohen's use of the word "type" in Der Begriff der Religion is not fully correct (because the individual value of the human being represented by art is located in a sphere of illusion, it is not denied from every point of view), this use of the word "type" can be justified. This doesn't change the fact, however, that from a strictly aesthetic point of view, i.e. in philosophical reflections about the foundation of aesthetic consciousness, of artistic creation and of aesthetic Erlebnis, the attribution of individuality to the human being represented by art remains completely valid.

\section{References}

[1] Rosenzweig F., Einleitung. In: Cohen H. Jüdische Schriften. Vol. I: Ethische und religiöse Grundfragen, ed. B. Strauß. Berlin: C.A. Schwetschke \& Sohn; 1924. P. XIII-LXIV.

[2] Rosenzweig F., Einleitung. In: Rosenzweig F. Der Mensch und sein Werk. Gesammelte Schriften. Vol. III: Zweistromland. Kleinere Schriften zu Glauben und Denken, ed. R. Mayer and A. Mayer. Dordrecht, Boston, Lancaster: Martinus Nijhoff; 1984. P. 177-223.

[3] Cohen H. Der Begriff der Religion im System der Philosophie. Gießen: Töpelmann; 1915. Anastatic reprint Hildesheim et al.: Olms; 1996.

[4] Cohen H. Die dramatische Idee in Mozarts Operntexten. Berlin: Bruno Cassirer; 1916.

[5] Cohen H. Die dramatische Idee in Mozarts Operntexten. In: Cohen H. Werke. vol. 17: Kleinere Schriften 6: 1916-1918, ed. H. Wiedebach. Hildesheim et al.: Olms; 2002. P. 1-108.

[6] Cohen H. System der Philosophie. Dritter Teil: Ästhetik des reinen Gefühls. 2 Vols. Berlin: Bruno Cassirer; 1912. Anastatic reprint Hildesheim et al.: Olms; 1982.

${ }^{7}$ See [3. P. 92]. However, the same concept is exposed far more clearly and incisively in a note dating to the same years when Cohen was writing Ästhetik des reinen Gefühls; see [8. P. 19]. 
[7] Cohen H. System der Philosophie. Erster Teil: Logik der reinen Erkenntnis. 2nd ed. Berlin: Bruno Cassirer; 1914. Anastatic reprint Hildesheim et al.: Olms; 1977.

[8] Cohen H. Werke. Supplementa. Vol. I: Reflexionen und Notizen, ed. H. Wiedebach. Hildesheim et al.: Olms; 2003.

\title{
Проблема индивидуальности в эстетике Германа Когена
}

\author{
Э. Гамба \\ Богословский Университет Северной Италии - Турин \\ Ул. 20 Сентября, 83, I-10122, Турин, Италия
}

\begin{abstract}
Франц Розенцвейг уделял особое внимание проблеме индивидуальности в философии Германа Когена. Он пишет, что в отличие от религиозного человека «человек, помещаемый в эстетическое поле, в своей эстетической индивидуальности превращается в ,простой тип“». Это утверждение основано на работе Когена «Эстетика чистого чувства» («Ӓsthetik des reinen Gefühls» (1912)): Коген утверждает, что человек, являющийся объектом эстетического представления, является не типом, а скорее индивидуальностью. Однако всего через три года в своей первой книге по философии религии «Der Begriff der Religion im System der Philosophie» (1915) Коген пишет о том, что эстетический субъект, представленный искусством, не является индивидуальностью, а только простым типом, так как индивидуальностью может быть только религиозный человек.

Цель данной статьи состоит в отображении разных посылок данных тезисов. С эстетической точки зрения человек, представленный искусством, должен рассматриваться как индивидуальность, в то время как системный подход, отображенный в «Der Begriff der Religion», показывает, что индивидуальность человека, представленного искусством, не может поддерживаться вне эстетической точки зрения.
\end{abstract}

Ключевые слова: Герман Коген, Франц Розенцвейг, эстетика, индивидуальность, искусство

\section{История статьи:}

Статья поступила 05.06.2019

Статья принята к публикации 10.07.2019

Для цитирования: Ezio Gamba. The Problem of Individuality in Hermann Cohen's Aesthetics // Вестник Российского университета дружбы народов. Серия: Философия. 2019. Т. 23. № 4. C. 413 - 419. doi: 10.22363/2313-2302-2019-23-4-413-419

\section{Сведения об авторе:}

Эиио Гамба - профессор БогословскогоУниверситета Северной Италии, Турин (e-mail: eziogamba@vodafone.it). 